\section{1-Methylcyclopropene Counteracts Fry Color Darkening Attributable to Carbon Dioxide and Ethylene Interaction}

\author{
Barbara J. Daniels-Lake', Robert K. Prange, Stephanie D. Bishop, and \\ Kimberly Hiltz \\ Agriculture and Agri-Food Canada, Atlantic Food and Horticulture \\ Research Centre, 32 Main Street Kentville, Nova Scotia, B4N 1J5 Canada
}

Additional index words. Solanum tuberosum, potato storage, reducing sugars, modified atmosphere, $\mathrm{CO}_{2}$, SmartFresh ${ }^{\mathrm{TM}}$

\begin{abstract}
The fry color of potatoes (Solanum tuberosum L.) stored for processing remains an important quality characteristic that can be affected by many factors, including ethylene gas from various sources and the interaction of very low concentrations of ethylene gas (less than $1 \mu \mathrm{L} \cdot \mathrm{L}^{-1}$ ) and accumulated $\mathrm{CO}_{2}$. Because previous studies show that pretreatment with 1-methylcyclopropene (1-MCP) can substantially reduce fry color darkening attributable to applied ethylene, we hypothesized that 1-MCP could also reduce fry color darkening attributable to the interaction of ethylene and $\mathrm{CO}_{2}$. Trials were conducted over two storage seasons, using 'Russet Burbank' tubers, either untreated or treated with $0.5 \mu \mathrm{L} \cdot \mathrm{L}^{-1}$ ethylene gas $\pm 2 \mathrm{kPa} \mathrm{CO}_{2}$ and $\pm 1-\mathrm{MCP}$. Tubers exposed to ethylene gas had darker fry color than untreated tubers, whereas the fry color of tubers exposed to ethylene plus $\mathrm{CO}_{2}$ was darker still. However, the fry color of tubers pretreated with 1-MCP was as light as that of the untreated tubers. This provides a potential new tool for the potato industry to manage potato fry color of stored processing potatoes.
\end{abstract}

Approximately half of the potatoes (Solanum tuberosum L.) grown in North America are consumed as French fries or potato chips. For the processors who make these products, fry color is a vitally important quality characteristic. The preferred light fry color depends on low reducing sugar concentrations in the raw tubers (Burton et al., 1992; Mazza, 1983). Although researchers and industry experts have long believed that elevated $\mathrm{CO}_{2}$ in the storage atmosphere results in increased reducing sugars and hence darkening of fry color, it has recently been shown that this is true only when a trace concentration of ethylene gas is also present (Daniels-Lake et al., 2005b).

Ethylene gas can increase reducing sugar concentrations in potato tubers, leading to darkening of fry color (Daniels-Lake et al., 2005a; Haard, 1971; Prange et al., 1998). The ethylene blocking compound 1-methylcyclopropene (1-MCP) has been shown to prevent

Received for publication 1 May 2008. Accepted for publication 24 July 2008.

Contribution \#2355, Atlantic Food and Horticulture Research Centre, Agriculture and Agri-Food Canada.

We thank Dr. Kenneth McRae for expert guidance in statistics, Dr. John Delong and Doug Nichols for reviewing the manuscript, and Valerie Simmons for technical assistance.

${ }^{1}$ To whom reprint requests should be addressed; e-mail DanielsLakeB@agr.gc.ca darkening of potato fry color attributable to ethylene (Prange et al., 2005). It was hypothesized that 1-MCP may prevent darkening attributable to the interaction of ethylene and $\mathrm{CO}_{2}$, and trials were conducted to test this hypothesis.

\section{Materials and Methods}

Trials were conducted during 2 consecutive years, i.e., Jan. to June 2004 and Dec. 2004 to June 2005, using commercially grown 'Russet Burbank' potatoes harvested in mid-October of the preceding growing season. Each year, the potato tubers were sourced from four different commercial potato growers located in eastern Canada. After arrival at the lab site, the potatoes were stored for 4 weeks at $13{ }^{\circ} \mathrm{C}$ to permit suberization and wound healing and then gradually cooled to $9{ }^{\circ} \mathrm{C}$ over 4 weeks and dipped in early December in a $1 \%$ a.i. water emulsion of chlorpropham [Sprout-Nip EC, isopropyl n-(3-chlorophenyl) carbamate, 320 g. $\mathrm{L}^{-1}$ a.i.; Stanchem Inc., Etobicoke, Ontario, Canada; CIPC] to control sprouting. Two 9week trial repetitions were conducted consecutively in each year, the first from January to March and the second from April to June. In the 2004 to 2005 storage season, half of the samples were treated and evaluated 3 weeks earlier than the remaining half in each trial.

Samples of 10 tubers $(\approx 2 \mathrm{~kg})$ were placed in mesh bags and stored at $9{ }^{\circ} \mathrm{C}$ in $0.1-\mathrm{m}^{-3}$ sealed aluminum chambers during the trials.
Each chamber held six samples at the start of each trial and each treatment was applied to two chambers. Samples from two of the potato sources were assigned to one of the pair of chambers receiving the same treatment according to the statistical design. Relative humidity within the chambers was maintained at $95 \%$ to $99 \%$ throughout the trials. The chambers were housed within a refrigerated cold room, which maintained the desired temperature $\pm 0.3{ }^{\circ} \mathrm{C}$ in all chambers throughout the trials.

Storage chamber atmospheres were modified by flushing with compressed gases (Praxair Inc., Dartmouth, Nova Scotia, Canada) to achieve concentrations of $19 \mathrm{kPa} \mathrm{O}_{2}$ with or without $2 \mathrm{kPa} \mathrm{CO}$ and $0.5 \mu \mathrm{L} \cdot \mathrm{L}^{-1}$ ethylene gas in a factorial arrangement. Chamber atmospheres were refreshed with appropriate compressed gas mixtures four times per day to maintain the desired gas concentrations. Ambient and respired $\mathrm{CO}_{2}$ was scrubbed from the $0 \mathrm{kPa} \mathrm{CO}$ chamber atmospheres by placing a paper sack containing $\approx 0.5 \mathrm{~kg}$ of hydrated lime $\left[\mathrm{Ca}(\mathrm{OH})_{2}\right.$; Graymont (QC) Inc., Boucherville, Quebec, Canada] inside the appropriate chambers. To simulate conditions in a poorly ventilated potato storage building, chambers that were not flushed between evaluation dates were used with $0.5 \mu \mathrm{L} \cdot \mathrm{L}^{-1}$ ethylene gas added to their atmosphere. The atmosphere of the unventilated chambers was gradually modified by cellular respiration of the tubers (depleted $\mathrm{O}_{2}$ and increased $\mathrm{CO}_{2}$ ) but returned to ambient conditions at 3 -week intervals when the chambers were opened to remove samples for evaluation. Ethylene gas was reintroduced after the chambers were resealed. Control chambers were flushed with medical-grade compressed air. In 2004, lime was used to scrub $\mathrm{CO}_{2}$ from the control chambers, but in the 2004 to 2005 trials, the $\mathrm{CO}_{2}$ was not scrubbed from the control chambers. The 1-MCP (SmartFresh ${ }^{\mathrm{TM}}$; AgroFresh Inc., Springhouse, PA) was applied inside the storage chambers just before the start of ethylene and $\mathrm{CO}_{2}$ delivery at the rate specified on the product label (nominally 0.9 $\mu \mathrm{L} \cdot \mathrm{L}^{-1}$ ) using the method described in Prange et al. (2005). The 12 treatments applied in all trials are summarized in Table 1.

The gas delivery apparatus was as described in Daniels-Lake et al. (2005b). The concentrations of $\mathrm{O}_{2}$ and $\mathrm{CO}_{2}$ were measured several times per week with a handheld gas monitor (CheckPoint; PBI Dansensor America, Glen Rock, NJ), and gas delivery rates were adjusted manually as needed to maintain desired gas concentrations. Ethylene concentrations were monitored automatically as described in Daniels-Lake et al. (2005b)

On arrival in October of each year and again at the start of each trial, three samples of tubers from each source were evaluated. After 3, 6, and 9 weeks in each trial, one sample from each source $\times$ treatment combination was evaluated. Fry color was evaluated at each date using the methods described in Daniels-Lake et al. (2005b). 


\begin{tabular}{|c|c|c|c|c|c|}
\hline \multirow[b]{2}{*}{ Treatment name } & \multicolumn{4}{|c|}{ Composition of chamber atmosphere } & \multirow{2}{*}{$\begin{array}{c}\text { Pretreated } \\
\text { with } \\
1-\mathrm{MCP}^{\mathrm{z}}\end{array}$} \\
\hline & $\begin{array}{c}\mathrm{CO}_{2} \\
\text { scrubbed }\end{array}$ & $\begin{array}{c}\mathrm{O}_{2} \\
(\mathrm{kPa})\end{array}$ & $\begin{array}{l}\mathrm{CO}_{2} \\
(\mathrm{kPa})\end{array}$ & $\begin{array}{l}\text { Ethylene } \\
\left(\mu \mathrm{L} \cdot \mathrm{L}^{-1}\right)\end{array}$ & \\
\hline Control & $\begin{array}{c}\text { 2004: yes } \\
\text { 2004-2005: no }\end{array}$ & Ambient & $\begin{array}{c}\text { 2004: } 0 \\
\text { 2004-05: } 0-0.3\end{array}$ & 0 & No \\
\hline Ethylene & Yes & Ambient & 0 & 0.5 & No \\
\hline Unventilated $^{y}+$ ethylene & No & Declining ${ }^{x}$ & Rising ${ }^{\mathrm{w}}$ & 0.5 & No \\
\hline Unventilated $^{\mathrm{y}}+$ Eth $^{\mathrm{v}}+1-\mathrm{MCP}$ & No & Declining $^{\mathrm{x}}$ & Rising ${ }^{\mathrm{w}}$ & 0.5 & Yes \\
\hline Reduced $\mathrm{O}_{2}$ & Yes & 19 & 0 & 0 & No \\
\hline Reduced $\mathrm{O}_{2}+\mathrm{CO}_{2}$ & No & 19 & 2 & 0 & No \\
\hline Reduced $\mathrm{O}_{2}+1-\mathrm{MCP}$ & Yes & 19 & 0 & 0 & Yes \\
\hline Reduced $\mathrm{O}_{2}+\mathrm{CO}_{2}+1-\mathrm{MCP}$ & No & 19 & 2 & 0 & Yes \\
\hline Reduced $\mathrm{O}_{2}+$ Eth & Yes & 19 & 0 & 0.5 & No \\
\hline Reduced $\mathrm{O}_{2}+\mathrm{CO}_{2}+$ Eth & No & 19 & 2 & 0.5 & No \\
\hline Reduced $\mathrm{O}_{2}+$ Eth $+1-\mathrm{MCP}$ & Yes & 19 & 0 & 0.5 & No \\
\hline Reduced $\mathrm{O}_{2}+\mathrm{CO}_{2}+$ Eth $+1-\mathrm{MCP}$ & No & 19 & 2 & 0.5 & Yes \\
\hline
\end{tabular}

${ }^{\mathrm{z}} 1$-methylcyclopropene, an ethylene-blocking compound.

${ }^{y}$ Atmosphere in the sealed chambers was gradually modified by cellular respiration of the tubers between evaluations. At each evaluation date, the chambers were opened briefly, which allowed the chamber atmospheres to return to ambient. Ethylene was reintroduced into the chambers after they were resealed. ${ }^{\mathrm{x}} \mathrm{O}_{2}$ declined to a minimum of $\approx 16 \mathrm{kPa}$ in these treatments as a result of tuber respiration.

${ }^{\mathrm{w}} \mathrm{CO}_{2}$ from tuber respiration accumulated to a maximum of $\approx 4 \mathrm{kPa}$ in these treatments.

${ }^{v}$ Ethylene gas.
The customized experimental design was a replicated split-split plot. The main plots were the chambers; the subplot was tuber source and sample (preassigned to evaluation dates) was the subsubplot. Data were analyzed by a generalized analysis of variance using Genstat V statistical software (Genstat Committee, 1993), which partitioned the tion and randomization of the design. When significant differences $(P \leq 0.05)$ were identified, data were compared using the least

\section{Results and Discussion}

'Russet Burbank' is recognized as a relatively long-dormancy cultivar. Thus, tubers stored at 8 to $10{ }^{\circ} \mathrm{C}$ without sprout inhibitors normally begin to sprout in late February to mid-March. Observation of the residual tubers held at $9{ }^{\circ} \mathrm{C}$ in common storage confirmed this to be true of the material used in these trials (data not presented). In view of the sources of variation according to the replicasignificant difference. timing of these trials, it is reasonable to assume that in both years, the tubers assessed in trials that started in December or January were still dormant (designated the dormant trials), whereas tubers in the trials that started in March were no longer dormant (designated the nondormant trials).

Although the treatment and storage of half of the samples started 3 weeks earlier than the second half in 2004 to 2005, statistical comparison indicated that they were not significantly different from each other within the dormant trial; similarly, the halves within the nondormant trial were not different (data not presented). Therefore, the data were treated as replicates within each trial.

In general, fry color was lighter in 2003 to 2004 than in 2004 to 2005 [75.1 versus 70.5 Agtron percent reflectance units $(\mathrm{ARu})$, respectively]. Fry color was slightly darker in the dormant trials than in the nondormant trials (71.7 versus 73.9 ARu, respectively). In addition, the range of observed fry colors was much wider in the nondormant trials than in
Table 2. Fry color of potatoes stored for 9 weeks with or without ethylene gas, elevated $\mathrm{CO}_{2}$, and/or 1-methylcyclopropene.

\begin{tabular}{|c|c|c|}
\hline \multirow[b]{2}{*}{ Treatment $^{2}$} & \multicolumn{2}{|c|}{ Fry color (Agtron \% reflectance units) } \\
\hline & Dormant tubers & Nondormant tubers \\
\hline Control & 74.7 & 79.2 \\
\hline Ethylene & 70.6 & 66.1 \\
\hline Unventilated + ethylene & 66.0 & 56.0 \\
\hline Unventilated + Eth $+1-\mathrm{MCP}$ & 73.9 & 78.5 \\
\hline Reduced $\mathrm{O}_{2}$ & 73.7 & 82.1 \\
\hline Reduced $\mathrm{O}_{2}+\mathrm{CO}_{2}$ & 70.2 & 78.9 \\
\hline Reduced $\mathrm{O}_{2}+1-\mathrm{MCP}$ & 73.9 & 79.7 \\
\hline Reduced $\mathrm{O}_{2}+\mathrm{CO}_{2}+1-\mathrm{MCP}$ & 71.6 & 79.1 \\
\hline Reduced $\mathrm{O}_{2}+$ Eth & 70.2 & 67.8 \\
\hline Reduced $\mathrm{O}_{2}+\mathrm{CO}_{2}+$ Eth & 68.5 & 60.8 \\
\hline Reduced $\mathrm{O}_{2}+$ Eth $+1-\mathrm{MCP}$ & 74.0 & 80.8 \\
\hline Reduced $\mathrm{O}_{2}+\mathrm{CO}_{2}+$ Eth $+1-\mathrm{MCP}$ & 72.7 & 77.9 \\
\hline F probability & \multicolumn{2}{|c|}{$<0.001$} \\
\hline estimated standard error & \multicolumn{2}{|c|}{2.099} \\
\hline Least significant difference, $5 \%$ confidence level & \multicolumn{2}{|c|}{5.891} \\
\hline
\end{tabular}

${ }^{\mathrm{z}}$ Treatments as described in Table 1. the dormant trials (26.1 versus 8.7 Aru, respectively). This suggests that dormant and nondormant tubers responded differently to the applied treatments, particularly in treatments including ethylene (Table 2). Because there were no significant treatment $x$ year or treatment $\times$ year $\times$ evaluation date interactions, only the treatment $\times$ trial results are discussed.

Previous investigation showed that fry color was unaffected by reduction of the $\mathrm{O}_{2}$ concentration in the storage atmosphere to $19 \%$ nor by increasing the $\mathrm{CO}_{2}$ concentration to $2 \%$ alone or in combination (Daniels-Lake et al., 2005b). Similar results were observed in these trials (Table 2). Scrubbing out the $\mathrm{CO}_{2}$ also had no significant effect on tuber fry color (data not presented).

In both the dormant and nondormant trials, potatoes stored with ethylene but without $\mathrm{CO}_{2}$ had darker fry color than the controls, although the difference was not significant in the dormant trials (Table 2). This is consistent with previous findings (Daniels-Lake et al., 2005a), which demonstrated that even low concentrations of ethylene (less than $1 \mu \mathrm{L} \cdot \mathrm{L}^{-1}$ ) can darken fry color. In contrast, the fry color of tubers stored with ethylene and $\mathrm{CO}_{2}$ together was darker than the controls in both trials (Table 2 ). In the nondormant trials, the fry color of tubers stored with ethylene and $\mathrm{CO}_{2}$ together was also darker than with ethylene only as shown previously (Daniels-Lake et al., 2005b).

When 1-MCP was applied to tubers before exposure to the modified atmosphere treatments, the effects of both ethylene and ethylene plus $\mathrm{CO}_{2}$ on fry color were reduced (Table 2). In both the dormant and nondormant trials, the fry color of tubers exposed to 1-MCP before treatment with ethylene plus $\mathrm{CO}_{2}$ was as light as the fry color of control tubers. In the nondormant trials, and in the unventilated treatment in the dormant trials, fry color of tubers treated with 1-MCP before exposure to ethylene plus $\mathrm{CO}_{2}$ was lighter than without 1-MCP pretreatment (Table 2).

These results support the hypothesis that the ethylene-blocking compound 1-MCP can protect stored potato tubers from fry color darkening attributable to the interaction of ethylene and $\mathrm{CO}_{2}$. However, research also suggests some variability among cultivars in the strength and duration of the protective effect of 1-MCP (Daniels-Lake et al., unpublished data). Additional work is warranted to further elucidate the responses of important cultivars. Nonetheless, 1-MCP pretreatment is a potential new tool to help the potato industry retain good fry color during longterm storage if registration for use on this commodity can be obtained.

\section{Literature Cited}

Burton, W.G., A. van Es, and K.J. Hartmans. 1992. The physics and physiology of storage, p. 608727. In: Harris, P.M. (ed.). The potato crop: The scientific basis for improvement. 2nd Ed. Chapman and Hall, London, UK. 
Daniels-Lake, B.J., R.K. Prange, J. Nowak, S.K. Asiedu, and J.R. Walsh. 2005a. Sprout development and processing quality changes in potato tubers stored under ethylene: 1 . Effects of ethylene concentration. Amer. J. Potato Res. 82:389-397.

Daniels-Lake, B.J., R.K. Prange, and J.R. Walsh. 2005b. Carbon dioxide and ethylene: A combined influence on potato fry color. HortScience 40:1824-1828.
Genstat Committee. 1993. Genstat release 3: Reference manual. Clarendon Press, Oxford, UK.

Haard, N.F. 1971. Differential response of coldstored potato tubers to ethylene. Amer. Potato J. 48:183-186.

Mazza, G. 1983. Correlations between quality parameters of potatoes during growth and long-term storage. Amer. Potato J. 60:145159 .
Prange, R.K., B. Daniels-Lake, J.-C. Jeong, and M. Binns. 2005. Effects of ethylene and 1-methylcyclopropene on potato tuber sprout control and fry color. Amer. J. Potato Res. 82: 123-128.

Prange, R.K., W. Kalt, B. Daniels-Lake, C.L. Liew, R.T. Page, J.R. Walsh, P. Dean, and R. Coffin. 1998. Using ethylene as a sprout control agent in stored 'Russet Burbank' potatoes. J. Amer. Soc. Hort. Sci. 123:463-469. 